
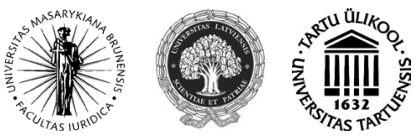

ISSN 1392-6195 (print)

\title{
KONFIDENCIALUMO REIKALAVIMŲ TEISINIAI PAGRINDAI VIEŠUOSIUOSE PIRKIMUOSE
}

\author{
Dainius Kenstavičius \\ Mykolo Romerio universiteto Teisès fakulteto \\ Konstitucinès ir administracinès teisès institutas \\ Ateities g. 20, LT-08303 Vilnius, Lietuva \\ Tel. +37069585000 \\ Elektroninis paštas: dainius@kenstavicius.lt
}

Pateikta 2014 m. rugpjūčio 2 d., parengta spausdinti 2014 m. rugsèjo 18 d.

doi:10.13165/JUR-14-21-3-08

\section{tvadas}

Viešųjų pirkimų procedūrų metu perkančiosios organizacijos turi pareigą tretiesiems asmenims neatskleisti tiekèjų pasiūlymų konfidencialios informacijos. Tuo tarpu tiekejjai, dalyvaujantys viešuosiuose pirkimuose, turi teisę susipažinti tiek su vykdomomis procedūromis, tiek su kitų tiekejjų pasiūlymais, todèl viešųjų pirkimų procedūrų ir kilusių ginčų metu svarbu yra atrasti tinkamą pusiausvyrą tarp viešojo intereso užtikrinti skaidrias ir teisètas pirkimų procedūras bei privataus intereso, kad konfidenciali informacija nebūtų atskleista. Siekiant išspręsti nurodytą problemą šios publikacijos tikslas yra išanalizuoti pareigos užtikrinti konfidencialumą teisinius pagrindus.

Siekiant išsiaiškinti konfidencialumo pareigos teisinius pagrindus pirmiausia reikia išanalizuoti, kokie duomenys sudaro konfidencialią informaciją, t. y. kokia yra konfidencialios informacijos samprata. Be to, siekiant atskleisti nagrinejjamą temą analizuojama, kokiais atvejais konfidenciali informacija gali ir turi būti atskleista. Šiuo aspektu svarbiausia yra rasti tinkamą balansą tarp konfidencialumo pareigos

Jurisprudencija/Jurisprudence

(C) Mykolo Romerio universitetas, 2014

(C) Mykolas Romeris University, 2014
ISSN 1392-6195 (print), ISSN 2029-2058 (online) http://www.mruni.eu/lt/mokslo_darbai/jurisprudencija/ http://www.mruni.eu/en/mokslo_darbai/jurisprudencija/ 
ir viešųjų pirkimų skaidrumo principo bei tarp konfidencialumo pareigos ir viešojo intereso užtikrinimo principo.

Šios publikacijos mokslinio tyrimo objektą pirmiausia sudaro perkančiųjų organizacijų pareiga neatskleisti vieno tiekejo pasiūlyme nurodytos konfidencialios informacijos kitiems tiekèjams. Analizuojama tiek užsienio mokslinè literatūra, tiek Lietuvos Respublikos teismų praktika. Temos probleminiai aspektai visų pirma yra susiję su viešųjų pirkimų procedūrų ir kilusių ikiteisminių bei teisminių ginčų metu tiekejjų pateiktais prašymais susipažinti su kitų tiekẻjų (konkurentų) tam tikromis pasiūlymų dalimis. Publikacijoje tyrinejjama perkančiosios organizacijos ir ginčą sprendžiančios institucijos pareiga neatskleisti kitų tiekejų pasiūlymuose esančios konfidencialios informacijos bei konfidencialumo pareigos ribos. Dažniausiai praktinès problemos kyla nustatant, kokia yra konfidencialios informacijos samprata ir kas gali būti laikoma konfidencialia informacija bei sprendžiant, kiek perkančiosios organizacijos ir teismai turi laisvès atskleisti vieno tiekejjo informaciją kitiems tiekejjams.

Siekiant tinkamai atskleisti temą teisinių dokumentų analizès metodu atskleidžiamas Lietuvos Respublikos ir Europos Sąjungos teisès teisinis reguliavimas, susijęs su konfidencialumo pareigos ịtvirtinimu viešuosiuose pirkimuose. Taip pat analizuojama su nagrinejamais klausimais bei tema susijusi Lietuvos Respublikos teismų ir Europos Sąungos Teisingumo Teismo jurisprudencija. Analizuojant Lietuvos bei Europos Sąjungos teisės mokslininkų darbus taikytas sisteminès analizės bei lyginamasis metodai. Atlikta analizè susisteminta ir atitinkamos išvados pateiktos apibendrinimo metodu.

Literatūros, kurioje būtų iš esmès nagrinejama konfidencialumo pareiga viešųjų pirkimų procedūrų metu, Lietuvos Respublikoje beveik nèra, kas, inter alia, pagrindžia temos aktualumą. Temos aktualumą suponuoja ir tai, kad teisinis reguliavimas yra gana lakoniškas, o pagrindinis nagrinejjamos temos šaltinis šiuo metu iš esmès tẻra Lietuvos Respublikos teismų bei Europos Sąjungos Teisingumo Teismo formuojama praktika. Nagrinejjamos temos mokslinè analizè padètų išanalizuoti konfidencialumo pareigos viešuosiuose pirkimuose ịgyvendinimo modelį, jo turinį ir bruožus.

\section{Konfidencialumo reikalavimų teisinis reguliavimas}

Kaip minèta, vienas pagrindinių nagrinejjamos temos šaltinių šiuo metu yra egzistuojantis teisinis reguliavimas, todèl siekiant tinkamai atskleisti temą pirmiausia yra būtina nuodugni šiuo metu nustatyto teisinio reguliavimo analizè. Konfidencialumo pareiga ir jos teisiniai pagrindai yra ịtvirtinti Lietuvos Respublikos viešụjų pirkimų ịstatyme ${ }^{1}$, Lietuvos Respublikos civilinio proceso kodekse ${ }^{2}$, taip pat Europos

1 Lietuvos Respublikos viešųjų pirkimų ịstatymas. Valstybės žinios. 1996, Nr. 84-2000.

2 Lietuvos Respublikos civilinio proceso kodeksas. Valstybès žinios. 2002, Nr. 36-1340. 
Sąjungos direktyvose - šiuo metu galiojančiose direktyvose 2004/17/EB ir 2004/18/ EB bei jau priimtose ir nuo $2016 \mathrm{~m}$. balandžio 18 d. pradèsiančiose veikti direktyvose 2014/24/EU ir 2014/25/EU. Todèl siekiant išsamiai atskleisti konfidencialumo pareigos teisinius pagrindus daugiausiai bus analizuojamas minètų teisès aktų reguliavimas.

Lietuvos Respublikos viešųjų pirkimų įstatymo 6 str. konfidencialumo pareiga yra įtvirtinta perkančiosios organizacijos, jos pirkimo komisijos, jos narių ir ekspertų bei kitų asmenų atžvilgiu. Minètoje teisès normoje ịtvirtinta konfidencialumo pareiga kyla iš Europos Sąjungos teisinio reguliavimo. Šiuo aspektu yra svarbi 2004 m. kovo 31 d. Europos Parlamento ir Tarybos direktyva 2004/17/EB „Dèl subjektų, vykdančių veiklą vandens, energetikos, transporto ir pašto paslaugų sektoriuose, vykdomų pirkimų tvarkos derinimo" (toliau - Direktyva 2004/17/EB). Šios direktyvos 13 str. 2 d. nustato pareigą perkančiosioms organizacijoms neatskleisti ūkio subjektų pateiktos informacijos, kurią jie pažymèjo kaip konfidencialią. Direktyva nustato, kad konfidenciali informacija apima visų pirma technines ir prekybos paslaptis bei konfidencialiuosius pasiūlymų aspektus. Kitos minètos direktyvos nuostatos yra susijusios su perkančiųjų organizacijų ir tiekejų bendravimu. Direktyvos 2004/17/EB 48 str. 3 d. nustato pareigą bendraujant ir mainantis informacija užtikrinti paraiškų dalyvauti konfidencialumą. Panaši nuostata yra ịtvirtinta ir Direktyvos 2004/17/EB 64 str. 2 d.

Kita svarbi direktyva, susijusi su perkančiųjų organizacijų pareiga užtikrinti konfidencialumą, yra $2004 \mathrm{~m}$. kovo $31 \mathrm{~d}$. Europos Parlamento ir Tarybos direktyva 2004/18/EB „Dèl viešojo darbų, prekių ir paslaugų pirkimo sutarčių sudarymo tvarkos derinimo" (toliau - Direktyva 2004/18/EB). Šios direktyvos 6 str. nustato pareigą perkančiosioms organizacijoms neatskleisti ūkio subjektų pateiktos informacijos, kurią jie pažymejjo kaip konfidencialią. Direktyva nustato, kad konfidenciali informacija apima visų pirma technines ir prekybos paslaptis bei konfidencialiuosius pasiūlymų aspektus.

Direktyvos 2004/18/EB 6 str. nustato, kad ị konfidencialios informacijos sąvoką patenka "technikos ir prekybos paslaptys ir konfidencialūs pasiūlymų aspektai“, tačiau detalesnis paaiškinimas nèra pateiktas. Toks pat teisinis reguliavimas yra nustatytas ir Direktyvos 2004/17/EB 13 str. 2 d. Be to, minèti direktyvų straipsniai taip pat ittvirtina, kad „perkančioji organizacija neturi atskleisti ūkio subjektų jai atsiųstos informacijos, kurią jie pažymèjo kaip konfidencialią“. Naujosios Europos Sąjungos direktyvos nustato, kad nustatant konfidencialios informacijos sąvoką technikos ir prekybos paslaptimis ir konfidencialiais pasiūlymų aspektais nèra apsiribojama.

Mokslinèje literatūroje ${ }^{3}$ svarstoma, kad direktyvų 2004/18/EB ir 2004/17/EB nuostatos nèra iki galo ir visiškai aiškios. Viena iš galimų šių nuostatų interpretacija yra ta, kad direktyvos draudžia konfidencialios informacijos atskleidimą tik tiek, 
kiek yra uždrausta valstybės ịstatymo reguliavimo lygmenyje, kas reiškia, kad, pažeidus nacionalinius ịstatymus dèl konfidencialios informacijos apsaugos ir naudojimo, automatiškai būtų laikoma, kad yra pažeisti ir atitinkami direktyvų straipsniai. Kita galima interpretacija yra ta, kad direktyvų nuostatos užtikrina laisvę tiekèjams pažymėti, kurią informaciją jie laiko konfidencialia. Tokiu atveju kyla klausimas, ar perkančiosios organizacijos turi teisę nustatyti sąlygas, pagal kurias tiekejjai bus priversti atskleisti tam tikrą informacijos dalį siekiant užtikrinti skaidrumą ir sąžiningą konkurenciją. Atsakymas ị minètą klausimą nèra iki galo aiškus, bet laikytina, kad perkančiosioms organizacijoms tokia teisè turètų būti suteikta. Tačiau labiau linkstama manyti, kad direktyvose pateikiamos nuorodos ị nacionalinę teisę reiškia, jog konfidenciali informacija gali būti atskleista tuomet, kai toks atskleidimas yra būtinas pagal nacionalinę teisę ${ }^{4}$.

Kaip matyti, Direktyvos 2004/17/EB ir Direktyvos 2004/18/EB teisinis reguliavimas dèl perkančiųjų organizacijų pareigos neatskleisti konfidencialios informacijos iš esmès sutampa. Labai panašus teisinis reguliavimas yra ịtvirtintas ir naujosiose Europos Sąjungos viešųjų pirkimų direktyvose - $2014 \mathrm{~m}$. vasario $26 \mathrm{~d}$. Europos Parlamento ir Tarybos direktyvoje 2014/24/EU „Dèl viešųjų pirkimų, kuria panaikinama Direktyva 2004/18/EB“ (toliau - „Direktyva 2014/24/EU“) ir 2014 m. vasario 26 d. Europos Parlamento ir Tarybos direktyvoje 2014/25/EU „Dèl subjektų, vykdančiu veiklą vandens, energetikos, transporto ir pašto paslaugų sektoriuose, vykdomų pirkimų, kuria panaikinama Direktyva 2004/17/EB“ (toliau - „Direktyva 2014/25/EU“). Šios direktyvos turès būti perkeltos ị nacionalinę teisę iki $2016 \mathrm{~m}$. balandžio $18 \mathrm{~d}$. Direktyvos 2014/24/EU 21 str. 1 d. yra ịtvirtinta, kad jei šioje direktyvoje arba perkančiajai organizacijai taikomoje nacionalinëje teisëje, visų pirma teisès aktuose dèl teises gauti informaciją, nenurodyta kitaip, ir nedarant poveikio pareigoms, susijusioms su paskirtų sutarčių viešinimu ir informacijos teikimu kandidatams ir konkurso dalyviams, kaip nustatyta 50 ir 55 straipsniuose, perkančioji organizacija neatskleidžia ekonominès veiklos vykdytojų jai perduotos informacijos, kurią jie nurodè kaip konfidencialią, ịskaitant technikos ar prekybos paslaptis ir konfidencialius pasiūlymų aspektus, bet jais neapsiribojant. Iš esmès analogiška nuostata yra įtvirtinta ir Direktyvos 2014/25/EU 39 str. 1 d. Kaip matyti, naujųjų Europos Sąjungos direktyvų konfidencialumo pareigos viešuosiuose pirkimuose teisinis reguliavimas iš esmès panašus. İvertinus šią aplinkybę bei tai, kad šiuo metu vis dar galioja anksčiau priimtos direktyvos, šiame straipsnyje daugiau dèmesio skiriama Direktyvos 2004/17/EB ir Direktyvos 2004/18/EB nuostatoms.

Anksčiau minètų Direktyvos 2004/17/EB ir Direktyvos 2004/18/EB nuostatos buvo tiesiogiai perkeltos ị Lietuvos Respublikos viešųjų pirkimų ịstatymo 6 str. Be kita ko, Lietuvos Respublikos viešųjų pirkimų ỉstatymo 6 str. 1 d. papildomai nustato, kad pasiūlyme nurodyta prekių, paslaugų ar darbų kaina, išskyrus jos sudedamąsias 
dalis, nèra laikoma konfidencialia informacija. Ši nuostata buvo priimta vèliau ir ịsigaliojo tik nuo 2014 m. sausio 1 d. Tokiu būdu Lietuvos Respublikoje yra įstatymiškai itvirtinta tam tikra informacija (pasiūlyme nurodyta kaina), kuri savo esme negali būti laikoma konfidencialia.

Istatyme yra nustatyti ir kiti pasiūlymų duomenys, kurie savo esme negali būti laikomi konfidencialiais. Pavyzdžiui, Lietuvos Respublikos viešųjų pirkimų istatymo 31 str. 6 d. nustato pareigą perkančiajai organizacijai, jeigu pageidauja nors vienas vokų su pasiūlymais atplèšimo procedūroje dalyvaujantis tiekèjas ar jo atstovas, paskelbti visas pasiūlymų charakteristikas, $\mathfrak{i}$ kurias bus atsižvelgta vertinant pasiūlymus. Be to, Lietuvos Respublikos viešųjų pirkimų ỉstatymo 41 str. 2 d. 2 p. nustato perkančiosios organizacijos pareigą nurodyti tiekejjui, kurio pasiūlymas nebuvo atmestas, - laimèjusio pasiūlymo charakteristikas ir santykinius pranašumus, dèl kurių šis pasiūlymas buvo pripažintas geriausiu, taip pat ši pasiūlymą pateikusio dalyvio ar preliminariosios sutarties šalių pavadinimus.

Lietuvos Respublikos viešųjų pirkimų ịstatymo 6 str. $1 \mathrm{~d}$. taip pat nustato papildomą taisyklę, pagal kurią dalyvių reikalavimu perkančioji organizacija turi juos supažindinti su kitų dalyvių pasiūlymais, išskyrus tą informaciją, kurią dalyviai nurodè kaip konfidencialią. Ši nuostata yra tiesiogiai susijusi su perkančiosios organizacijos pareiga saugoti konfidencialią informaciją, tačiau yra skirta priešingai perkančiosios organizacijos pareigai ịtvirtinti - pareigai leisti susipažinti tiekejjams su kitų tiekejjų pasiūlymais toje dalyje, kurioje tiekejjai nepažymèjo informacijos kaip konfidencialios. Lietuvos Respublikos viešujų pirkimų ịstatymo 6 str. 1 d. nustato tokias pačias taisykles kaip ir direktyvos, išskyrus išimtị dèl informacijos, kuri negali būti laikoma konfidencialia. Minèta ịstatymo norma nustato, kad pasiūlyme nurodyta prekių, paslaugų ar darbų kaina, išskyrus jos sudedamąsias dalis, nèra laikoma konfidencialia informacija.

Minètas teisinis reguliavimas savo esme nustato pakankamai didelę laisvę patiems tiekẻjams pasirinkti, kuri informacija turi būti laikoma konfidencialia. Lietuvos Respublikoje tiekèjai vis dažniau (pastaruoju metu - beveik visada) pasiūlymuose nurodo, kuri informacija yra laikoma konfidencialia. Taikant minètas direktyvas bei Lietuvos Respublikos viešųjų pirkimų įstatymą susiduriama su atvejais, kai tiekejjai visą (arba beveik visą) pasiūlymą pažymi kaip konfidencialią informaciją. Lingvistiškai aiškinant Direktyvą 2004/17/EB ir Direktyvą 2004/18/EB bei Lietuvos Respublikos viešųjų pirkimų ịstatymo 6 str. galima būtų daryti išvadą, kad, tiekejjams pažymėjus tam tikrą informaciją kaip konfidencialią, perkančiosios organizacijos ar ginčą nagrinèjančios institucijos jokiais būdais negalètų visos tokios informacijos atskleisti kitiems tiekejams. Tačiau toks aiškinimas būtų itin formalus, neatitinkantis kitų viešųjų pirkimų teisès normų, itvirtintų tiek minètose direktyvose, tiek Lietuvos Respublikos viešųjų pirkimų ịstatyme.

Galiausiai pažymėtina, kad nors Direktyva 2004/17/EB, Direktyva 2004/18/EB ir Lietuvos Respublikos viešųų pirkimų įstatymas tiesiogiai to nereguliuoja, tačiau 
pareiga užtikrinti tiekejų konfidencialią informaciją tenka ne tik perkančiajai organizacijai, bet ir ginčą nagrinejjančioms institucijoms - teismams. Lietuvos Respublikos civilinio proceso kodekso $423^{8}$ str. 1 d. yra nustatyta, kad teismas turi teisę savo iniciatyva rinkti ịrodymus, kuriais šalys nesiremia, jeigu, jo nuomone, tai yra būtina siekiant teisingai išspręsti bylą. Teismai, išreikalavę tam tikrus įrodymus, turi užtikrinti informacijos konfidencialumą, kai siunčia procesinius dokumentus kitiems proceso dalyviams ${ }^{5}$. Europos Sąjungos Teisingumo Teismas yra nurodęs, kad už viešojo pirkimo procedūrų peržiūrą atsakinga institucija nepatenka tarp subjektų, kuriems negalima suteikti konfidencialios ir komercinę paslaptị turinčios informacijos, tačiau ji pati privalo užtikrinti minètų duomenų slaptumą ${ }^{6}$.

\section{Konfidencialios informacijos samprata}

Siekiant tiksliai nustatyti konfidencialumo pareigos teisinius pagrindus, būtina atskleisti, kokie duomenys patenka ị konfidencialios informacijos sąvoką. Nei Lietuvos Respublikos viešujų pirkimų ịstatyme, nei Europos Sąjungos direktyvose, reguliuojančiose viešuosius pirkimus, konfidencialios informacijos samprata nėra tiksliai atskleista.

Lietuvos Respublikos viešųjų pirkimų ịstatyme nesant nustatytų išsamių taisyklių, pagal ịstatymo analogiją taikytinas Lietuvos Respublikos civilinis kodeksas tiek, kiek jis neprieštarauja viešųjų pirkimų teisiniam reguliavimui. Pagal Lietuvos Aukščiausiojo Teismo nuosekliai formuojamą praktiką Lietuvos Respublikos viešųjų pirkimų ịstatymas yra lex specialis, t. y. kitų teisès aktų nuostatos viešųjų pirkimų teisiniams santykiams turi būti taikomos subsidiariai - pirmiausia reikia taikyti galiojančias Lietuvos Respublikos viešųjų pirkimų įstatymo nuostatas, o kitos teisès normos taikytinos tais atvejais, kai Lietuvos Respublikos viešųjų pirkimų ịstatymas nereguliuoja atitinkamo klausimo arba šiame įstatyme yra įtvirtintos blanketinès nuostatos. Be to, negalima Lietuvos Respublikos viešųjų pirkimų įstatymo nuostatų aiškinti ir taikyti taip, kad būtų nukrypta nuo kitų teisès aktų teisès normų, o šių taikymas negali būti laikomas prieštaraujančiu Lietuvos Respublikos viešųjų pirkimų įstatymo nuostatų taikymui, nebent Lietuvos Respublikos viešųjų pirkimų i̇statyme expressis verbis būtų itvirtintas priešingas reguliavimas?

Konfidencialios informacijos sąvoka, kuri yra taikoma ir viešųjų pirkimų teisiniams santykiams, yra ittvirtinta Lietuvos Respublikos civilinio kodekso 1.116 str.

5 Weiner, K. Towards European Preferences? Implications of Directive 2009/81/EC on Domestic Preferences in Defense Procurement. The procurement lawyer. 2012 (Spring), p. 18.

6 Europos Sąjungos Teisingumo Teismo $2008 \mathrm{~m}$. vasario $14 \mathrm{~d}$. sprendimas byloje Nr. C-450/06, Varec.

7 Lietuvos Aukščiausiojo Teismo Civilinių bylų skyriaus teisèjų kolegijos $2012 \mathrm{~m}$. liepos $5 \mathrm{~d}$. nutartis civilineje byloje $U A B$ „CSC Telecom " $v$. Valstybinio socialinio draudimo fondo valdyba prie Lietuvos Respublikos socialinés apsaugos ir darbo ministerijos, bylos Nr. 3K-3-359/2012. 
1 d., pagal kurią informacija laikoma komercine (gamybine) paslaptimi, jeigu turi tikrą ar potencialią komercinę (gamybinę) vertę dèl to, kad jos nežino tretieji asmenys ir ji negali būti laisvai prieinama dèl šios informacijos savininko ar kito asmens, kuriam savininkas ją yra patikèjęs, protingų pastangų išsaugoti jos slaptumą.

Lietuvos Respublikos teisès doktrinoje dalis autorių laikosi pozicijos, kad konfidencialios informacijos turiniui yra keliami iš esmès du reikalavimai:

1) informacijos vertingumas, reikšmingumas ir naudingumas. Informacija yra laikoma vertinga ir reikšminga, jeigu bendrovè, pritaikiusi tam tikrą technologiją, kuri nustatyta bei ifforminta kaip bendrovès komercinè paslaptis, pasiekia gerų rezultatų parduodama produktą - skirtumas tarp ankstesnių bendrovès pajamų ir pajamų pritaikius naująsias technologijas pasireiškia realia (tikra) nauda bendrovei. Informacija, kurios panaudojimas ir apsauga nuo trečiųjų asmenų gali turèti tikrą vertę ateityje, laikoma turinčia potencialią vertę, tačiau tokią informaciją yra sunkiau nustatyti ir pagrịsti;

2) informacijos formalizavimas ir identifikavimas. Informacija, kaip komerciné paslaptis, turi būti konkrečiai apibrěžiama (formalizuojama). Tam sudaromas komercinę paslaptị sudarančių žinių (informacijos) sąrašas, nustatomi asmenys, kuriems atliekant pareigas gali būti suteikiama teisè susipažinti su komercinę paslaptị sudarančiomis žiniomis. Taip pat parengiama tokių asmenų supažindinimo su komercinę paslaptị sudarančiomis žiniomis ir jų perspejjimo apie šių žinių atskleidimą ar praradimą tvarka. Informacija turi būti užfiksuota taip, kad būtų galima patikrinti, ar ji atitinka slaptumo ir reikšmingumo kriterijus, ir užtikrinti, pavyzdžiui, kad tokios informacijos savininkui be priežasties nebūtų trukdoma panaudoti savo gamybinę ar kitokio pobūdžio technologiją ${ }^{8}$.

Lietuvos Aukščiausiasis Teismas, aiškindamas konfidencialios informacijos sąvoką ir kriterijus, yra nustatęs šiuos būtinus požymius, kuriuos privalo atitikti konfidenciali informacija:

1) informacija turi būti slapta (nevieša). Komercinę paslaptị sudaro tik tokia informacija, kuri nèra visuotinai žinoma ar laisvai prieinama tretiesiems asmenims. Tai, kad nurodyta informacija nèra visuotinai žinoma, nereiškia, jog informacija turi būti absoliučiai slapta;

2) informacija turi turèti tikrą ar potencialią komercinę (gamybinę) vertę dèl to, kad jos nežino tretieji asmenys ir ji negali būti laisvai prieinama. Konfidenciali informacija turi suteikti jos turètojui konkurencini pranašumą, t. y. tam tikrų verslo privalumų, gamybinio pranašumo, finansinès naudos ir pan.;

3) informacija turi būti slapta dèl jos savininko ar kito asmens, kuriam savininkas ją yra patikẻjęs, protingų pastangų išsaugoti jos slaptumą. Ar asmuo 
èmėsi priemonių saugoti informaciją, vertinama pagal tai, ar jis prièmé sprendimą paskelbti konkrečius duomenis kaip saugotinus ir èmėsi protingų saugos priemonių. Pastangos turètų būti „protingos“, bet ne „ypatingos“, nes tai nepagrịstai susiaurintų komercinès paslapties ribas ${ }^{9}$.

Konfidencialios informacijos sąvokos turinį svarbu nustatyti ir dèl tos priežasties, kad už pareigos neatskleisti konfidencialios informacijos gresia teisinè atsakomybė. Pavyzdžiui, Jungtinėse Amerikos Valstijose už konfidencialios informacijos atskleidimą tam tikromis aplinkybėmis gresia net ir baudžiamoji atsakomybè tiems asmenims, kurie žino, jog gauna ar atskleidžia konfidencialią informaciją, ir tik tokiu atveju, jeigu toks atskleidimas ar informacijos gavimas buvo atliktas su tikslu gauti naudą arba suteikti ar igyti konkurencinį pranašumą ${ }^{10}$. Toks teisinis reguliavimas yra tikslingas dèl tos priežasties, kad ilguoju laikotarpiu tiekejjai gali pradèti vengti dalyvauti procedūrose, kurių metu nèra tinkamai vertinama konfidencialios informacijos apsauga $^{11}$.

Mokslinèje literatūroje ir teismų praktikoje nurodyti kriterijai dèl informacijos priskyrimo konfidencialiai informacijai yra taikytini ir viešųjų pirkimų teisiniams santykiams. Sutariama, kad tiekejjui nebūtų tinkama nurodyti absoliučiai visos pasiūlymo informacijos konfidencialia ${ }^{12}$. Tačiau dèl viešųjų pirkimų tikslo ir teisinio reguliavimo skirtini tam tikri specifiniai ir papildomi kriterijai, $\mathfrak{i}$ kuriuos turètų būti atsižvelgiama nustatant konfidencialios informacijos pobūdị bei reikalavimus siekiant nustatyti, ar yra pagrindas bei būtinybè atskleisti tam tikrą tiekejjo pateiktos informacijos dali.

\section{Konfidencialumo pareigos santykis su viešųjų pirkimų skaidrumo principu}

Skaidrumo principas yra vienas esminių viešųjų pirkimų principų, įtvirtintų Lietuvos Respublikos viešųjų pirkimų įstatymo 3 str. 1 d. Lietuvos Respublikos kasacinis teismas nuosekliai laikosi pozicijos, kad viešųjų pirkimų principai yra ne tik

9 Lietuvos Aukščiausiojo Teismo Civilinių bylų skyriaus 2013 m. spalio 18 d. nutartis civilinèje byloje $U A B$ „Rüdupis“ v. Varénos rajono savivaldybès administracija ir kt., bylos Nr. 3K-3495/2013; Lietuvos Aukščiausiojo Teismo Civilinių bylų skyriaus teisejų kolegijos $2012 \mathrm{~m}$. birželio 26 d. nutartis civilineje byloje $U A B$ „Diteilas“ $v$. UAB „Chemika“ ir kt., bylos Nr. 3K-3$326 / 2012$.

10 Timothy, M. Is the Procurement Integrity Act Important Enough for the Mandatory Disclosure Rule - A Case for Inclusion. Public Contract Law Journal. 2011, 40 (2): 353.

11 Timothy, M. Promoting Integrity from Without: A Call for the Military to Conduct outside, Independent Investigations of Alleged Procurement Integrity Act Violations. Air Force Law Review. 2010, 66: 235.

12 Arrowsmith, S. EU Public Procurement Law: an Introduction. University of Nottingham [interaktyvus]. Jungtiné Karalyste, 2011 [žiūrèta 2014-05-10]. <http://www.nottingham.ac.uk/ pprg/documentsarchive/asialinkmaterials/eupublicprocurementlawintroduction.pdf>. 
perkančiųjų organizacijų ir tiekèjų teisių bei pareigų viešojo pirkimo srityje tiesioginis šaltinis, bet ir tiesiogiai taikytinos teisés normos - vien viešųjų pirkimų principų pažeidimo konstatavimas, nesiremiant jokia papildoma norma, yra pakankamas pagrindas reikalauti teismo pripažinti neteisètais perkančiosios organizacijos veiksmus $^{13}$. Viešųų pirkimų principų laikymasis ir tinkamas jų taikymas nėra tik besąlyginė perkančiųjų organizacijų Lietuvos Respublikos viešųjų pirkimų ịstatymo normų, būtent 3 straipsnio nuostatų, laikymosi pareiga, bet ir viešųjų pirkimų tikslų pasiekimo garantas ${ }^{14}$.

Viešųjų pirkimų principų reikšmę sunku pervertinti vien dèl to, kad jų pažeidimas reiškia imperatyviųjų teisès normų pažeidimą. Vien viešųjų pirkimų principų pažeidimo konstatavimas, nesiremiant jokia papildoma norma, yra pakankamas pagrindas reikalauti teismo pripažinti neteisètais perkančiosios organizacijos veiksmus $^{15}$.

Skaidrumas yra suprantamas kaip viešumo užtikrinimas vykdant viešojo pirkimo procedūras. Skaidrumo principas reiškia perkančiosios organizacijos pareigą tiekejjams suteikti pakankamai informacijos, ịskaitant pirkimo sąlygas, jų išaiškinimus, reikalingus perkančiosios organizacijos poreikius atitinkančiam pasiūlymui, bei informacijai, susijusiai su konkretaus tiekèjo pasiūlymo ịvertinimu, pateikti. Dèl šių priežasčių Lietuvos Aukščiausiasis Teismas teisingai pastebi, kad skaidrumo principo taikymas, pasireiškiantis viešumo garantijų igyvendinimu, dažnai sukelia koliziją tarp konfidencialumo pareigos ir viešumo ${ }^{16}$.

Savo ruožtu Europos Sąjungos Teisingumo Teismas pripažǐsta, kad skaidrumo principas padeda užtikrinti viešųjų pirkimų lygiateisiškumo principą ${ }^{17}$. Teisinèje literatūroje yra skiriami keturi skaidrumo principo elementai: 1) pirkimo sutarčių viešumas; 2) kiekvienos viešųjų pirkimų procedūros taisyklių viešumas; 3) normomis pagrịstas sprendimų priẻmimas, apribojantis perkančiųjų organizacijų diskreciją; 4) sprendimų patikrinimo ir įvykdymo galimybès ${ }^{18}$.

13 Lietuvos Aukščiausiojo Teismo Civilinių bylų skyriaus teisèjų kolegijos $2013 \mathrm{~m}$. spalio $4 \mathrm{~d}$. nutartis civilinėje byloje UAB „PricewaterhouseCoopers“ v. Valstybinè mokesčiu inspekcija, bylos Nr. 3K-3-474/2013.

14 Lietuvos Aukščiausiojo Teismo Civilinių bylų skyriaus teisèjų kolegijos $2013 \mathrm{~m}$. balandžio 2 d. nutartis civilineje byloje $U A B$ „Pontem“ $v$. Plungès rajono savivaldybès administracija, bylos Nr. 3K-3-198/2013.

15 Lietuvos Aukščiausiojo Teismo Civilinių bylų skyriaus teisejjų kolegijos $2013 \mathrm{~m}$. vasario $22 \mathrm{~d}$. nutartis civilineje byloje VI Klaipédos laivu statybos ir remonto mokykla $v$. UAB „Projektu rengimo biuras", bylos Nr. 3K-3-43/2013.

16 Lietuvos Aukščiausiojo Teismo Civilinių bylų skyriaus $2013 \mathrm{~m}$. spalio $18 \mathrm{~d}$. nutartis civilinèje byloje UAB „Rūdupis“ v. Varénos rajono savivaldybès administracija ir kt., bylos Nr. 3K-3495/2013.

17 Europos Sajungos Teisingumo Teismo $2001 \mathrm{~m}$. spalio 18 d. sprendimas byloje SIAC Construction Nr. C-19/00.

18 Arrowsmith, S., supra note 3, p. 430. 
Europos Sąungos Teisingumo Teismas atskirais atvejais yra pripažinęs, jog siekiant užtikrinti skaidrumo principą būtina atskleisti tam tikrą informaciją, nors direktyvos tiesiogiai neịpareigoja tokios informacijos atskleisti ${ }^{19}$.

Užsienio autoriai daro išvadą, kad teismai turi taip aiškinti viešųjų pirkimų teisinị reguliavimą, kad būtų sudarytos kiek įmanoma didesnès galimybės užtikrinti skaidrumo principą ${ }^{20}$. Ivertinus skaidrumo principo tiesioginị įtvirtinimą teisiniame reguliavime, taip pat skaidrumo principo reikšmę, kurią suteikia tiek Lietuvos Respublikos teismai, tiek Europos Sąjungos Teisingumo Teismas bei kitų valstybių nacionaliniai teismai ir mokslinè literatūra, darytina išvada, kad skaidrumo principas negali būti laikomas tik atspindinčiu koliziją tarp konfidencialumo pareigos ir viešumo. Skaidrumo principo pažeidimas yra absoliutaus pobūdžio, kas savaime lemia priimtų perkančiosios organizacijos sprendimų neteisètumą. Viešųjų pirkimų procedūros privalo būti viešos, todèl skaidrumo principo užtikrinimas yra vienas iš reikšmingiausių kriterijų sprendžiant, ar konkrečiu atveju konfidencialia pažymėta informacija galètų ir turètų būti atskleista.

Be abejonès, skaidrumo principas negali būti aiškinamas absoliučiai, t. y. visiškai paneigiant informacijos konfidencialumo galimybę. Konfidencialios informacijos apsauga nèra vertybẻ pati savaime - dažnai ji padeda užtikrinti didžiausią konkurenciją viešuosiuose pirkimuose ${ }^{21}$. Tačiau viešųjų pirkimų teisinių santykių specifika skaidrumo principui suteikia ypatingą reikšmę, todèl konkrečiu atveju kilus abejonių dèl informacijos konfidencialaus pobūdžio konfidencialios informacijos sąvoka turi būti aiškinama siaurai, kiek įmanoma didesnę reikšmę suteikiant skaidrumo principui, t. y. informacijos išviešinimui. Kitaip tariant, klausimai dèl konfidencialios informacijos atskleidimo turètų būti sprendžiami ieškant teisingos ir protingos pusiausvyros tarp konfidencialumo ir skaidrumo principų.

\section{Konfidencialumo pareigos santykis su viešuoju interesu}

Viešųjų pirkimų teisiniai santykiai yra susiję ir su viešuoju interesu. Lietuvos Aukščiausiasis Teismas pripažista, jog Lietuvos Respublikos viešujų pirkimų įstatymo imperatyviosios nuostatos bei viešųjų pirkimų principai yra susiję su viešojo intereso apsauga ${ }^{22}$. Ne tik pats viešųjų pirkimų teisinis reguliavimas, bet ir viešųjų

19 Europos Sąjungos Teisingumo Teismo 2002 m. gruodžio 12 d. sprendimas byloje Nr. C-470/99, Universale-Bau.

20 Arrowsmith, S., supra note 3, p. 431.

21 Timothy, M. Should the United States Incorporate the Procurement Integrity Act into Its Free Trade Agreements: A Look at the Australian-United States Free Trade Agreement. Southwestern Journal Of International Law. 2010, 17 (1): 127.

22 Lietuvos Aukščiausiojo Teismo Civilinių bylų skyriaus teisèjų kolegijos $2009 \mathrm{~m}$. lapkričio 17 d. nutartis civilineje byloje A. M. ir kt. v. Turto valdymo ir ükio departamentas prie Lietuvos Respublikos vidaus reikaly ministerijos ir kt., bylos Nr. 3K-3-508/2009. 
pirkimų ginčai taip pat yra susiję su viešojo intereso apsauga ${ }^{23}$. Viešųjų pirkimų teisinis reglamentavimas susijęs su viešojo intereso apsauga, todèl Lietuvos Respublikos viešųjų pirkimų ịstatyme viešiesiems pirkimams nustatyti specialūs reikalavimai, o šio įstatymo nuostatos aiškintinos ir taikytinos taip, kad būtų apgintas viešasis interesas $^{24}$. Tad viešasis interesas turi būti analizuojamas ir gali būti laikomas dar vienu kriterijumi, ̣̣ kurị turètų būti atsižvelgiama nustatant perkančiųjų organizacijų pareigą neatskleisti tiekejjų konfidencialios informacijos bei šios pareigos ribas.

Greta privataus intereso viešųjų pirkimų bylos pasižymi ir viešuoju interesu ${ }^{25}$ todèl šiose bylose privatus ir viešasis interesas pakankamai dažnai gali sutapti. Teisès pažeidimų nustatymas ir atitinkamų sankcijų prièmimas neabejotinai yra siektinas tikslas, kuris visiškai atitinka ir viešąjị interesą - užtikrinti, kad kiekvieno viešojo pirkimo procedūros būtų skaidrios ir teisètos bei užkirsti kelią bet kokiems neteisètiems piktnaudžiavimams.

Viešojo intereso sąvoką sudètinga tiksliai apibūdinti, bet paprastai yra laikoma, jog viešasis interesas apima pagrindinius principus, kuriais grindžiama valstybès teisinè sistema, valstybès ir visuomenès funkcionavimas ${ }^{26}$. Viešojo intereso sąvoka yra vertinamojo pobūdžio, jos turinys gali būti atskleidžiamas tik analizuojant konkrečios bylos aplinkybes. Bendrąja prasme viešieji interesai reiškia naudą visuomenei ar jos daliai, žmonių gerovę. Pagal Lietuvos Aukščiausiojo Teismo praktiką viešuoju interesu viešujų pirkimų teisiniuose santykiuose pripažįstamos dvi lygiavertès vertybės - visuomenès interesas tam tikru pirkimo objektu (preke, paslauga, darbų rezultatu) bei jo teikiama nauda ir visuomenès interesas užtikrinti konkurso dalyvių sąžiningą varžymąsi ${ }^{27}$. Pavyzdžiui, viešuoju interesu gali būti laikomas perkančiosios organizacijos poreikis ịsigyti pačią geriausią paslaugą, o kartais gali pasitaikyti, kad geriausia paslauga gali būti igyta tik sujungiant skirtingų tiekèjų pasiūlymus - tokiu

23 Lietuvos Aukščiausiojo Teismo Civilinių bylų skyriaus teisèjų kolegijos $2009 \mathrm{~m}$. lapkričio $13 \mathrm{~d}$. nutartis civilineje byloje IDT Biologika GmbH v. Lietuvos Respublikos valstybine maisto ir veterinarijos tarnyba, bylos Nr. 3K-3-506/2009.

24 Lietuvos Aukščiausiojo Teismo Civilinių bylų skyriaus teisèjų kolegijos $2011 \mathrm{~m}$. gruodžio 14 d. nutartis civilinèje byloje Viešuju pirkimu tarnyba $v$. Akmenès rajono savivaldybès administracija, uždaroji akciné bendrovè „Affecto Lietuva“, bylos Nr. 3K-3-507/2011.

25 Lietuvos Aukščiausiojo Teismo Civilinių bylų skyriaus teisèjų kolegijos 2009 m. lapkričio 13 d. nutartis civilineje byloje IDT Biologija GmbH v. Lietuvos Respublikos valstybine maisto ir veterinarijos tarnyba, bylos Nr. 3K-3-506/2009; Lietuvos Aukščiausiojo Teismo Civilinių bylų skyriaus teisèjų kolegijos $2008 \mathrm{~m}$. gruodžio $23 \mathrm{~d}$. nutartis civilinèje byloje $U A B$ „ERP“ $v$. Valstybine mokesčiu inspekcija, bylos Nr. 3K-3-583/2008.

26 Lietuvos Aukščiausiojo Teismo Civilinių bylų skyriaus teisejjų kolegijos $2012 \mathrm{~m}$. liepos $5 \mathrm{~d}$. nutartis civilineje byloje UAB „CSC Telecom" $v$. Valstybinio socialinio draudimo fondo valdyba prie Lietuvos Respublikos socialinés apsaugos ir darbo ministerijos, bylos Nr. 3K-3-359/2012.

27 Lietuvos Aukščiausiojo Teismo Civilinių bylų skyriaus teisèjų kolegijos $2011 \mathrm{~m}$. balandžio $5 \mathrm{~d}$. nutartis civilineje byloje $U A B$ „Smulkus urmas" $v$. Plungés rajono savivaldybés administracija, bylos Nr. 3K-3-155/2011. 
atveju atsiranda tam tikra ịtampa tarp perkančiųų organizacijų intereso pasirinkti patị geriausią sprendimą iš visų pateiktų pasiūlymų ir tarp reikalavimo užtikrinti tiekejų konfidencialios informacijos apsaugą ${ }^{28}$.

Viešujų pirkimų bylose teismai naudojasi didesne nei iprasta diskrecijos teise. Lietuvos Respublikos civilinio proceso kodekso $423^{8}$ str. 1 d. yra nustatyta, kad teismas turi teisę savo iniciatyva rinkti ịrodymus, kuriais šalys nesiremia, jeigu, jo nuomone, tai yra būtina siekiant teisingai išspręsti bylą. Toks teisinis reguliavimas suponuoja, kad viešųjų pirkimų bylose teismai turètų imtis aktyvesnio vaidmens ir taip siekti užtikrinti viešąj̣ interesą - esant reikalui, išsireikalauti ir susipažinti net ir su tiekejo konfidencialia informacija.

Pavyzdžiui, Jungtinès Karalystės teismai laiko, kad vien faktas, jog dokumentai yra konfidencialūs, nereiškia, jog tokie duomenys negali būti atskleisti ${ }^{29}$. Pagrindinis klausimas sprendžiant, ar duomenų atskleidimas ir analizė yra tikslingas, yra kiek toks atskleidimas yra būtinas siekiant teisingo bylos išnagrinèjimo, o jeigu yra nusprendžiama atskleisti konfidencialius duomenis - ar yra tikslingos specialiosios priemonès, tokios kaip duomenų redagavimas ar privataus teismo posėdžio surengimas $^{30}$. Autoriai, analizuojantys Jungtinès Karalystės teismų sprendimus, pažymi, kad konfidencialių duomenų atskleidimo klausimas turi būti sprendžiamas įvertinus visus galimus sprendimus derinant konfidencialumo ir teisingo teismo proceso principus $^{31}$. Kiti autoriai išdèsto panašią poziciją, jog turi būti ieškoma pusiausvyros tarp poreikio neatskleisti tretiesiems asmenims konfidencialios informacijos ir tarp reikalavimo atskleisti tokią informaciją siekiant užtikrinti tinkamą teismo procesą ${ }^{32}$.

Lietuvos Respublikos teismai, aiškindami teismo vaidmenį viešųjų pirkimų bylose, laikosi pozicijos, kad siekiant užtikrinti viešojo intereso apsaugą sprendžiant viešujų pirkimų ginčus, už jų nagrinejjimą atsakingam subjektui, t. y. teismui, turi būti suteikti plačiausi igaliojimai veikti. Šių plačių, iniciatyvos reikalaujančių teismo iggaliojimų (teisių) naudojimo galimybė egzistuoja ir sprendžiant dèl tokių perkančiosios organizacijos ir tiekejo ginčo aspektų, kurie nèra sureguliuoti bendrųjų ar specialiụjų teisès normų. Teismo pareiga ginti viešąji interesą - konstitucinè jo priedermé, tiesiogiai kylanti iš Lietuvos Respublikos Konstitucijos 109 straipsnio -

28 Bovis, C. The New Public Procurement Regime of the European Union: a Critical Analysis of Policy, Law and Jurisprudence. European Law Review. 2005, 30 (5): 613.

29 Jungtinès Karalystės Aukštojo teismo Karalienès suolo skyriaus Technologijų ir statybų teismo 2010 m. balandžio 27 d. sprendimas Croft House Care Ltd v Durham CC, Orchard Home Care Ltd $v$ Durham CC, Kelly Park Caring Agency v Durham CC [2010] EWHC 909 (TCC) (Ramsey J).

30 Jungtinès Karalystės Aukštojo Teismo Karalienès suolo skyriaus 2011 m. sausio 19 d. sprendimas byloje Mears Ltd v Leeds City Council [2011] EWHC 40 (QB).

31 Henty, P. Disclosure of information and time limits for proceedings in public procurement cases: Mears Ltd $v$ Leeds City Council. Public Procurement Law Review. 2011, 3: 93-96.

32 Henty, P. Healthcare at Home Ltd v Common Services Agency. Public Procurement Law Review. 2011, 3: 83-86. 
teismai vykdo teisingumą - bei kitų jos nuostatų, inter alia, konstitucinio teisinès valstybès principo ${ }^{33}$.

Neabejojama, kad viešųjų pirkimų procedūrų teisètumas ir perkančiosios organizacijos sprendimų pagrịstumas yra svarbus viešasis interesas. Lietuvos Respublikos kasacinis teismas yra pažymėjęs, kad galimybè viešąji interesą pirkimo objektu iškelti aukščiau už viešąji interesą tiekèjų sąžiningu varžymusi turi būti aiškinama ir taikoma siaurai, išimtinai ${ }^{34}$. Viešasis interesas pirkimo objektu reiškia, kad perkančioji organizacija turi laiku ịsigyti jai reikiamų prekių, paslaugų ir darbų, o jeigu pirkimo sutartis jau sudaryta ir vykdoma - kad nebūtų stabdomas jos vykdymas ir be pagrịsto pagrindo pirkimo sutartis nebūtų pripažinta negaliojančia ar taikomos kitos teisinès sankcijos. Tuo tarpu sąžiningas tiekèjų varžymasis bus užtikrintas tik tuomet, kai visos pirkimo procedūros bus skaidrios ir teisètos.

Kiti Lietuvos Respublikos teismai taip pat aktyviai aiškina Lietuvos Respublikos civilinio proceso kodekso $423^{8}$ str. $1 \mathrm{~d}$. ir teismo vaidmenị viešųjų pirkimų bylose. Lietuvos apeliacinis teismas laiko, kad minèta teisès norma ịpareigoja teismą sprendžiant viešųjų pirkimų ginčus būti aktyvų ir, esant reikalui, savo iniciatyva rinkti ịrodymus. Lietuvos apeliacinis teismas taip pat pažymi, kad viešųjų pirkimų bylos visuomet yra susijusios ir su viešojo intereso apsauga, todèl teismo aktyvus vaidmuo yra būtinas ir dèl visuomenès intereso užtikrinti skaidrias bei teisètas pirkimų procedūras $^{35}$. Lietuvos Respublikos Konstitucinio Teismo jurisprudencijoje yra konstatuota, kad viešojo intereso, kaip valstybès pripažinto ir teisès ginamo visuomeninio intereso, iggyvendinimas yra viena svarbiausiu pačios visuomenès egzistavimo ir raidos sąlygų ${ }^{36}$.

Konfidencialumo pareigos aspektu viešųjų pirkimų procedūrų metu susiduria viešasis interesas užtikrinti skaidrias ir teisètas pirkimų procedūras bei privatusis interesas, kad konfidenciali informacija nebūtų atskleista. Minètam privačiam interesui užtikrinti pasaulyje yra pasitelkiamos net baudžiamosios ar administracinès sankcijos - Jungtinių Amerikos Valstijų patirtis rodo, jog tik baudžiamųjų ir administracinių sankcijų ịtvirtinimas ịtikina viešųjų pirkimų dalyvius, jog konfidenciali informacija, skirta viešajam pirkimui, turi išlikti neatskleista ${ }^{37}$. Tačiau vertinant konstituciniu

33 Lietuvos Aukščiausiojo Teismo Civilinių bylų skyriaus teisejų kolegijos $2012 \mathrm{~m}$. liepos $5 \mathrm{~d}$. nutartis civilineje byloje UAB „CSC Telecom" $v$. Valstybinio socialinio draudimo fondo valdyba prie Lietuvos Respublikos socialines apsaugos ir darbo ministerijos, bylos Nr. 3K-3-359/2012.

34 Lietuvos Aukščiausiojo Teismo Civilinių bylų skyriaus teisejjų kolegijos $2013 \mathrm{~m}$. rugpjūčio $1 \mathrm{~d}$. nutartis civilinèje byloje Viešuju pirkimu tarnyba v. Vilniaus miesto savivaldybès administracija, $A B$,City Service“ ir kt., bylos Nr. 3K-3-415/2013.

35 Lietuvos apeliacinio teismo $2012 \mathrm{~m}$. gruodžio $28 \mathrm{~d}$. sprendimas civilineje byloje $A B$ „Eurovia Lietuva“ v. AB „Lietuvos geležinkeliai“ ir kt., bylos Nr. 2A-2384/2012.

36 Lietuvos Respublikos Konstitucinio Teismo 1997 m. gegužès 6 d. nutarimas. Valstybès žinios. 1997, Nr. 40-977; Lietuvos Respublikos Konstitucinio Teismo 2005 m. gegužès 13 d. nutarimas byloje Nr. 51/01-26/02-19/03-22/03-26/03-27/03. Valstybès žinios. 2005, Nr. 63-2235. 
požiūriu nei viešasis interesas skaidriomis ir teisètomis procedūromis, nei privatusis interesas išsaugoti konfidencialią informaciją neatskleistą neturi iš anksto viršesnès galios. Lietuvos Respublikos Konstitucinis Teismas yra išplètojęs konstitucinę doktriną, pagal kurią viešasis interesas, kaip bendras valstybès, visos visuomenės ar visuomenès dalies interesas, turi būti derinamas su individo autonominiais interesais, nes ne tik viešasis interesas, bet ir asmens teisès yra konstitucinès vertybès ${ }^{38}$. Kitoje byloje Lietuvos Respublikos Konstitucinis Teismas pažymėjo, kad Konstitucijoje įtvirtintos vertybės - asmens teisių ir teisètų interesų apsauga bei gynimas ir viešasis interesas negali būti priešinamos, ir šioje srityje būtina užtikrinti teisingą pusiausvyrą ${ }^{39}$.

Viešasis interesas suponuoja, kad tiekèjo pasiūlymo informacijos pažymèjimas kaip konfidencialios negali lemti absoliutaus draudimo atskleisti bent dali tokios informacijos. Svarbu užtikrinti, kad konfidencialios informacijos apsauga nesumenkintų viešųjų pirkimų tikslo viską uždengiant paslapties skraiste, kas būtų tiesiog nenuoširdus tiekèjo ar perkančiosios organizacijos pasiteisinimas siekiant nuslèpti aktualią informaciją nuo visuomenès ${ }^{40}$. Reikalavimas užtikrinti pirkimų procedūrų skaidrumą ir teisètumą reiškia, kad perkančioji organizacija ar teismas, nagrinèdamas ginčą, turètų išanalizuoti visas su konkrečia situacija susijusias faktines aplinkybes ir ịrodymus. Savo ruožtu tiekèjai turi turèti galimybę įsitikinti vykdomų pirkimų procedūrų skaidrumu ir pagrịstumu. Dèl šios priežasties informacija gali būti laikoma konfidencialia tik tuomet, kai tiekèjas ne formaliai, bet realiai pagrindžia būtinybę išsaugoti tokios informacijos slaptumą. Be to, tiek perkančiosios organizacijos, tiek teismai, spręsdami, ar konkreti informacija yra konfidenciali, neturètų apsiriboti vien formaliais konstatavimais dèl konfidencialumo, bet turètų visapusiškai pagrịsti informacijos slaptumo būtinybę bei ịvertinti, ar skaidrumo principas nelemia būtinybès atskleisti tam tikrą dalị konfidencialios informacijos. Tik tokiu būdu derinant viešąji interesą dèl skaidrių ir teisètų pirkimo procedūrų ir privatų interesą dèl konfidencialios informacijos apsaugos būtų galima užtikrinti tinkamą ir teisètą sprendimų prièmimą viešųjų pirkimų procedūrų bei ginčų nagrinejjimo metu.

\section{Išvados}

1. Konfidencialumo pareigos teisiniai pagrindai, ịtvirtinti Lietuvos Respublikos ir Europos Sąjungos teisès aktuose, susideda iš dviejų elementų: konfidencialios in-

38 Lietuvos Respublikos Konstitucinio Teismo 1997 m. gegužès 6 d. nutarimas. Valstybès žinios. 1997, Nr. 40-977; Lietuvos Respublikos Konstitucinio Teismo 2004 m. gruodžio 13 d. nutarimas byloje Nr. 51/01-26/02-19/03-22/03-26/03-27/03. Valstybès žinios. 2004, Nr. 181-6708.

39 Lietuvos Respublikos Konstitucinio Teismo 2006 m. rugsėjo 21 d. nutarimas byloje Nr. 35/0311/06. Valstybès žinios. 2006, Nr. 102-3957.

40 Savvides, D. Effectiveness of the Competitive Dialogue Procedure under the EU Consolidated Public Procurement Directive (2004/18/EC) as an Award Procedure for Public Private Partnerships. European Public Private Partnership Law Review. 2011, 6 (1): 35. 
formacijos sampratos bei pareigos neatskleisti informacijos, kurią tiekejjas pažymėjo kaip konfidencialią.

2. Konfidencialumo pareigos turinys ir jos ribos viešujų pirkimų procedūrų bei ginčų metu turètų būti nustatomas inter alia derinant konfidencialumo pareigą kartu su kitais viešujų pirkimų principais, pirmiausia - skaidrumo principu, keliančiu reikalavimą viešojo pirkimo procedūrų metu užtikrinti viešumą.

3. Kilus abejonių, ar tam tikra informacija gali būti laikoma konfidencialia, konfidencialios informacijos sąvoka turi būti aiškinama siaurai, kiek įmanoma didesnę reikšmę suteikiant viešųjų pirkimų skaidrumo principui, t. y. informacijos išviešinimui.

4. Viešųjų pirkimų skaidrumo principas lemia, kad reikalinga informacija būtų atskleista, o viešųjų pirkimų teisinis reguliavimas turètų būti aiškinamas taip, kad būtų sudarytos kiek įmanoma didesnès galimybès užtikrinti skaidrumo principą.

5. Viešojo pirkimo bylos pasižymi viešuoju interesu, kuris ịpareigoja teismą sprendžiant viešujų pirkimų ginčus būti aktyvų ir, esant reikalui, savo iniciatyva rinkti ịrodymus, pavyzdžiui, susipažinti su tiekejo konfidencialia informacija.

\section{Literatūra}

2004 m. kovo 31 d. Europos Parlamento ir Tarybos direktyva 2004/17/EB „Dèl subjektų, vykdančių veiklą vandens, energetikos, transporto ir pašto paslaugų sektoriuose, vykdomų pirkimų tvarkos derinimo". [2004] OL L 134, 30.4.2004, p. 1 .

2004 m. kovo 31 d. Europos Parlamento ir Tarybos direktyva 2004/18/EB „Dèl viešojo darbų, prekių ir paslaugų pirkimo sutarčių sudarymo tvarkos derinimo“. [2004] OL L 134, 30.4.2004, p. 114.

2014 m. vasario 26 d. Europos Parlamento ir Tarybos direktyva 2014/24/EU „Dèl viešujų pirkimų, kuria panaikinama Direktyva 2004/18/EB“. [2014] OL L 94, 28/03/2014, p. 65-242.

2014 m. vasario 26 d. Europos Parlamento ir Tarybos direktyva 2014/25/ EU „Dèl subjektų, vykdančių veiklą vandens, energetikos, transporto ir pašto paslaugų sektoriuose, vykdomų pirkimų, kuria panaikinama Direktyva 2004/17/EB“. [2014] OL L 94, 28/03/2014, p. 243-374.

Arrowsmith, S. EU Public Procurement Law: an Introduction. University of Nottingham [interaktyvus]. Jungtinè Karalystė, 2011 [žiūrèta 2014-05-10]. $<$ http://www.nottingham.ac.uk/pprg/ documentsarchive/asialinkmaterials/eupublicprocurementlawintroduction.pdf $>$.

Arrowsmith, S. The Law of Public and Utilities and Procurement. London: Sweet \& Maxwell, 2005.

Bovis, C. The New Public Procurement Regime of the European Union: a Critical Analysis of Policy, Law and Jurisprudence. European Law Review. 2005, 30 (5). 
Europos Sąjungos Teisingumo Teismo $2001 \mathrm{~m}$. spalio $18 \mathrm{~d}$. sprendimas byloje Nr. C-19/00, SIAC Construction.

Europos Sąungos Teisingumo Teismo 2002 m. gruodžio 12 d. sprendimas byloje Nr. C-470/99, Universale-Bau.

Europos Sąungos Teisingumo Teismo $2008 \mathrm{~m}$. vasario $14 \mathrm{~d}$. sprendimas byloje Nr. C-450/06, Varec.

Henty, P. Disclosure of information and time limits for proceedings in public procurement cases: Mears Ltd v Leeds City Council. Public Procurement Law Review. 2011, 3.

Henty, P. Healthcare at Home Ltd v Common Services Agency. Public Procurement Law Review. 2011, 3

Jungtinès Karalystès Aukštojo Teismo Karalienès suolo skyriaus $2011 \mathrm{~m}$. sausio 19 d. sprendimas byloje Mears Ltd $v$ Leeds City Council [2011] EWHC 40 (QB).

Jungtinès Karalystės Aukštojo teismo Karalienès suolo skyriaus Technologijų ir statybų teismo $2010 \mathrm{~m}$. balandžio 27 d. sprendimas Croft House Care Ltd v Durham CC, Orchard Home Care Ltd v Durham CC, Kelly Park Caring Agency v Durham CC [2010] EWHC 909 (TCC) (Ramsey J).

Lietuvos apeliacinio teismo $2012 \mathrm{~m}$. gruodžio $28 \mathrm{~d}$. sprendimas civilinèje byloje $A B$ „Eurovia Lietuva“ v. $A B$ „Lietuvos geležinkeliai“ ir kt., bylos Nr. 2A-2384/2012.

Lietuvos Aukščiausiojo Teismo Civilinių bylų skyriaus $2013 \mathrm{~m}$. spalio 18 d. nutartis civilinèje byloje $U A B, R \bar{u}$ dupis" v. Varénos rajono savivaldybes administracija ir $k t$., bylos Nr. 3K-3495/2013.

Lietuvos Aukščiausiojo Teismo Civilinių bylų skyriaus teisėjų kolegijos 2009 m. lapkričio $13 \mathrm{~d}$. nutarti civilinèje byloje IDT Biologija GmbH v. Lietuvos Respublikos valstybine maisto ir veterinarijos tarnyba, bylos $\mathrm{Nr}$. 3K-3$506 / 2009$.

Lietuvos Aukščiausiojo Teismo Civilinių bylų skyriaus teisejjų kolegijos $2008 \mathrm{~m}$. gruodžio $23 \mathrm{~d}$. nutartis civilinèje byloje $U A B$ „ERP“ v. Valstybine mokesčiu inspekcija, bylos Nr. 3K-3-583/2008.

Lietuvos Aukščiausiojo Teismo Civilinių bylų skyriaus teisejjų kolegijos $2012 \mathrm{~m}$. birželio $26 \mathrm{~d}$. nutartis civilinèje byloje $U A B$,Diteilas“ v. UAB ,Chemika“ ir kt., bylos Nr. 3K-3-326/2012.

Lietuvos Aukščiausiojo Teismo Civilinių bylų skyriaus teisèjų kolegijos 2012 $\mathrm{m}$. liepos $5 \mathrm{~d}$. nutartis civilinèje byloje $U A B$ „CSC Telecom“ v. Valstybinio socialinio draudimo fondo valdyba prie Lietuvos Respublikos socialinès apsaugos ir darbo ministerijos, bylos Nr. 3K3-359/2012.

Lietuvos Aukščiausiojo Teismo Civilinių bylų skyriaus teisèjų kolegijos 2013 m. spalio $4 \mathrm{~d}$. nutartis civilinèje byloje $U A B$ "PricewaterhouseCoopers" v. Valstybine mokesčiu inspekcija, bylos Nr. 3K-3-474/2013.

Lietuvos Aukščiausiojo Teismo Civilinių bylų skyriaus teisèjų kolegijos $2013 \mathrm{~m}$. balandžio $2 \mathrm{~d}$. nutartis civilineje byloje $U A B$ „Pontem“ v. Plunges rajono savivaldybès administracija, bylos Nr. 3K-3-198/2013.

Lietuvos Aukščiausiojo Teismo Civilinių bylų skyriaus teisejjų kolegijos $2013 \mathrm{~m}$. vasario $22 \mathrm{~d}$. nutartis civilinèje byloje VI Klaipedos laivu statybos ir remonto mokykla $v$. UAB „Projektu rengimo biuras", bylos Nr. 3K-3-43/2013.

Lietuvos Aukščiausiojo Teismo Civilinių bylų skyriaus teisèjų kolegijos 2009 m. 
lapkričio $17 \mathrm{~d}$. nutartis civilinèje byloje A. M. ir kt. v. Turto valdymo ir ükio departamentas prie Lietuvos Respublikos vidaus reikaly ministerijos ir $k t$., bylos Nr. 3K-3-508/2009.

Lietuvos Aukščiausiojo Teismo Civilinių bylų skyriaus teisèjų kolegijos 2009 m. lapkričio $13 \mathrm{~d}$. nutartis civilineje byloje IDT Biologika GmbH v. Lietuvos Respublikos valstybine maisto ir veterinarijos tarnyba, bylos $\mathrm{Nr}$. $3 \mathrm{~K}-3$ $506 / 2009$.

Lietuvos Aukščiausiojo Teismo Civilinių bylų skyriaus teisèjų kolegijos $2011 \mathrm{~m}$. gruodžio $14 \mathrm{~d}$. nutartis civilinèje byloje Viešuju pirkimu tarnyba v. Akmenès rajono savivaldybes administracija, uždaroji akcine bendrove „Affecto Lietuva“, bylos Nr. 3K-3-507/2011.

Lietuvos Aukščiausiojo Teismo Civilinių bylų skyriaus teisèjų kolegijos $2011 \mathrm{~m}$. balandžio $5 \mathrm{~d}$. nutartis civilinejje byloje $U A B$ „Smulkus urmas“ v. Plungès rajono savivaldybes administracija, bylos Nr. 3K-3-155/2011.

Lietuvos Aukščiausiojo Teismo Civilinių bylų skyriaus teisèjų kolegijos 2012 $\mathrm{m}$. liepos $5 \mathrm{~d}$. nutartis civilineje byloje $U A B$ „CSC Telecom“ $v$. Valstybinio socialinio draudimo fondo valdyba prie Lietuvos Respublikos socialines apsaugos ir darbo ministerijos, bylos Nr. 3K3-359/2012.

Lietuvos Aukščiausiojo Teismo Civilinių bylų skyriaus teisejjų kolegijos $2013 \mathrm{~m}$. rugpjūčio $1 \mathrm{~d}$. nutartis civilineje byloje Viešuju pirkimu tarnyba v. Vilniaus miesto savivaldybes administracija, $A B$, City Service“ ir kt., bylos Nr. 3K3-415/2013.

Lietuvos Respublikos civilinio proceso kodeksas. Valstybès žinios. 2002, Nr. 36-1340.
Lietuvos Respublikos Konstitucinio Teismo 1997 m. gegužès 6 d. nutarimas. Valstybès žinios. 1997, Nr. 40-977.

Lietuvos Respublikos Konstitucinio Teismo $2004 \mathrm{~m}$. gruodžio $13 \mathrm{~d}$. nutarimas byloje Nr. 51/01-26/02-19/03-22/0326/03-27/03. Valstybès žinios. 2004, Nr. 181-6708.

Lietuvos Respublikos Konstitucinio Teismo $2005 \mathrm{~m}$. gegužès $13 \mathrm{~d}$. nutarimas byloje Nr. 51/01-26/02-19/03-22/0326/03-27/03. Valstybès žinios. 2005, Nr. 63-2235.

Lietuvos Respublikos Konstitucinio Teismo $2006 \mathrm{~m}$. rugsejjo $21 \mathrm{~d}$. nutarimas byloje Nr. 35/03-11/06. Valstybès žinios. 2006, Nr. 102-3957.

Lietuvos Respublikos viešųjų pirkimų ìstatymas. Valstybès žinios. 1996, Nr. 84-2000.

Matkevičius, A. Bendrovès komercinès paslapties objektas. Jurisprudencija. 2007, 10(100).

Savvides, D. Effectiveness of the Competitive Dialogue Procedure under the EU Consolidated Public Procurement Directive (2004/18/EC) as an Award Procedure for Public Private Partnerships. European Public Private Partnership Law Review. 2011, 6 (1).

Timothy, M. Is the Procurement Integrity Act Important Enough for the Mandatory Disclosure Rule - A Case for Inclusion. Public Contract Law Journal. 2011, 40 (2).

Timothy, M. Promoting Integrity from Without: A Call for the Military to Conduct outside, Independent Investigations of Alleged Procurement Integrity Act Violations. Air Force Law Review. 2010, 66.

Timothy, M. Should the United States Incorporate the Procurement Integrity 
Act into Its Free Trade Agreements:

A Look at the Australian-United States Free Trade Agreement. Southwestern Journal of International Law. 2010, 17 (1).
Weiner, K. Towards European Preferences? Implications of Directive 2009/81/EC on Domestic Preferences in Defense Procurement. The procurement lawyer. 2012 (Spring).

Anotacija. Straipsnyje analizuojama konfidencialumo pareiga ir jos turinys viešųų pirkimų procedūrose bei konfidencialumo pareigos taikymo viešųjų pirkimų procedūrose pagrindinès taisyklès. Daroma išvada, kad pareiga užtikrinti konfidencialumą turi būti derinama su viešųjų pirkimų skaidrumo principu, iš esmės reiškiančiu viešumo užtikrinimą vykdant viešojo pirkimo procedūras.

Reikšminiai žodžiai: viešieji pirkimai, konfidencialumas, skaidrumas, viešasis interesas.

\section{LEGAL BASIS FOR THE DUTY OF CONFIDENTIALITY IN PUBLIC PROCUREMENT}

\section{Dainius Kenstavičius}

Mykolas Romeris University, Lithuania

Summary. The main focus of this article is the legal basis of the duty of confidentiality and its content during the procedures of public procurement and during the disputes regarding the legality of decisions made by the contracting authorities. Only those cases which are associated with contracting authorities' duty to keep information of other suppliers confidential are analyzed. The actual problems are related to the requests of a supplier in order to get certain information about other suppliers in pre-trial disputes and during litigation.

The legal basis of the duty of confidentiality is established in national law as well as in European Union Directives. Due to the relatively laconic legal regulation, case law becomes very important, which provides additional rules and practical solutions to the problems that arise. In order to analyze the legal basis of the duty of confidentiality, at first the conception of confidential information should be determined. The conception of confidential information is disclosed in other branches of the law. Secondly, the limits of duty to keep information confidential should be analyzed. However, the duty of confidentiality during the procurement procedures and legal disputes has its own specifics. The duty of confidentiality should be balanced with the principle of transparency, basically meaning the requirement of publicity during public procurement procedures. The principle of transparency is very important, because if this principle is violated, it is sufficient to require the court to declare illegal actions made by contracting authority. 
The general criteria for information to be held as confidential are also applicable to the public procurement of legal relationship, but there are some specific criteria. The principle of transparency often causes a conflict between the duty of confidentiality and publicity. However, it is necessary to disclose certain information, which means that public procurement legal regulation should be interpreted so as to allow the greatest possible opportunities to ensure transparency. Also, the duty of confidentiality quite often contradicts the public interest to ensure the transparent and legal public procedures. As a result, the public interest in public procurement litigation requires the court to be active and, if necessary, to collect evidence - if necessary, even the supplier's confidential information. The active role of the court is necessary to ensure transparent and legal public procurement procedures.

Keywords: public procurement, confidentiality, transparency, public interest.

Dainius Kenstavičius, Mykolo Romerio universiteto Teisès fakulteto Konstitucinès ir administracinès teisès instituto lektorius. Mokslinių tyrimų kryptys: lyginamoji konstitucinè teisè, viešųjų pirkimų teisè.

Dainius Kenstavičius, Mykolas Romeris University, Faculty of Law, Department of Constitutional and Administrative Law, lecturer. Fields of scientific research: comparative constitutional law, public procurement law. 